\title{
PENGARUH PERTUMBUHAN ASSET, PERTUMBUHAN PENJUALAN \\ DAN PROFITABILITAS TERHADAP STRUKTUR MODAL PADA PERUSAHAAN PERTAMBANGAN DI BURSA EFEK INDONESIA PERIODE 2015-2018
}

\author{
Putu Widhi Dharmaputra1, I Made Wianto Putra², A.A.A Erna \\ Trisnadewi ${ }^{3}$ \\ Program Studi Akuntansi \\ Fakultas Ekonomi dan Bisnis, Universitas Warmadewa, Bali, Indonesia \\ Email: wididarma69@gmail.com
}

\begin{abstract}
ABSTRAK
Struktur modal merupakan faktor penting yang perlu diperhatikan dalam suatu perusahaan. Perusahaan yang memiliki struktur modal yang padat utang dan memiliki tingkat risiko yang tinggi hal tersebut menunjukkan bahwa dalam kegiatan bisnisnya diperlukan adanya perhatian yang serius dalam penggunaan struktur modal. Pertumbuhan asset, pertumbuhan penjualan dan profitabilitas diperkirakan berpengaruh terhadap struktur modal. Tujuan penelitian adalah untuk mengetahui pengaruh pertumbuhan asset, pertumbuhan penjualandan profibilitas terhadap struktur modal pada Perusahaan Pertambangan di Bursa Efek Indonesia periode 2015-2018. Jumlah sampel dalam penelitia ini adalah sebanya 20 perusahaan pertambabangan yang secara rutin mengirimkan laporan selama tahun 2015-2018, serta mempunyai price earning rasio. Data dianalisis dengan menggunakan analisis regresi linier berganda. Hasil analisis menunjukkan bahwa pertumbuhan asset, pertumbuhan penjualan, dan profitabilitas berpengaruh positif dan signifikan terhadap struktur modal pada Perusahaan Pertambangan di Bursa Efek Indonesia periode 2015-2018.
\end{abstract}

Kata Kunci: Pertumbuhan Aset, Pertumbuhan Penjualan, Profitabilitas, dan Struktur Modal

\begin{abstract}
Capital structure is an important factor that needs to be considered in a company. Companies that have a debt-intensive capital structure and have a high level of risk shows that in their business activities serious attention is needed in the use of capital structures. Asset growth, sales growth and profitability are expected to influence capital structure. The purpose of this study was to determine the effect of asset growth, sales growth and profitability on the capital structure of Mining Companies on the Indonesia Stock Exchange in the 20152018 period. The number of samples in this research are 20 mining companies that routinely send reports during 2015-2018, and have a price earning ratio. Data
\end{abstract}


were analyzed using multiple linear regression analysis. The results of the analysis show asset growth, sales growth, and profitability has a positive and significant effect on capital structure in Mining Companies on the Indonesia Stock Exchange in the 2015-2018 period.

Keywords: Asset growth, Sales Growth, Profitability. Capital Structure

\section{A. PENDAHULUAN}

Perusahaan pada umumnya akan dihadapkan pada kondisi ketidak pastian ekonomi yang semakin tidak stabil karena pengaruh dari internal maupun eksternal perusahaan. Pengaruh internal terkait dengan kondisi manajerial perusahaan sedangkan kondisi ekternal perusahaan terkait dengan kondisi makro ekonomi tempat perusahaan tersebut didirikan maupun pengaruh dari negara luar. Peran manajer keuangan perusahaan dalam melakukan fungsi manajemen keuangan akan diperlukan untuk mengatasi hal tersebut. Fungsi manajemen keuangan dapat dilihat dari bagaimana manajer perusahaan melakukan keputusan investasi dan keputusan pendanaan yang tepat untuk kelangsungan hidup perusahaaan.

Struktur modal adalah faktor penting yang perlu diperhatikan dalam suatu perusahaan. Perusahaan yang memiliki struktur modal yang padat dengan utang dan memiliki tingkat risiko yang tinggi, maka hal tersebut menunjukkan bahwa dalam kegiatan bisnisnya diperlukan adanya perhatian yang serius dalam penggunaan struktur modal. Bursa Efek Indonesia dijadikan sebagai salah satu tempat bagi perusahaan yang akan mencari sumber modal untuk pembiayaan ekspansi usahanya. Hal tersebut dilakukan bagi setiap perusahaan yang ingin memerlukan tambahan modal untuk mengembangkan kegiatan bisnis di masa depan. Jika dilihat lebih jauh setiap sektor industri di Bursa Efek Indonesia seperti sektor properti, sektor pertambangan, dan sektor manufaktur memiliki karakteristik penggunaan utang yang berbeda. Hal tersebut dikarenakan kegiatan bisnis setiap sektor industri di Bursa Efek Indonesia memiliki perbedaan dalam menggunakan utang untuk kegiatan bisnisnya.

Penelitian ini menguji pengaruh pertumbuhan asset dan pertumbuhan penjualan terhadap struktur modal. Struktur modal dalam perusahaan pertambangan memiliki rata-rata komposisi tingkat utang yang tinggi jika dibandingkan dengan perusahaan non keuangan yang terdaftar di Bursa Efek 
Indonesia seperti perusahaan sektor properti dan sektor manufaktur. Perusahaanperusahaan yang didominasi dengan struktur modal yang tinggi akan memiliki risiko financial distress yang tinggi sehingga akan menyebabkan potensi kebangkrutan bagi perusahaan.

\section{B. TINJAUAN PUSTAKA}

\section{Struktur modal}

Struktur modal yang optimal merupakan keputusan keuangan yang penting bagi manajemen perusahaan karena struktur modal akan mempengaruhi kinerja dan nilai perusahaan. Kinerja perusahaan yang baik akan berdampak bagi harga sahamnya yang mengalami kenaikan di pasar modal, sehingga kemakmuran pemegang saham akan dicapai. Keputusan struktur modal juga akan sangat menentukan kemampuan perusahaan dalam melakukan aktivitas operasinya dan juga akan berpengaruh terhadap risiko perusahaan. Jika perusahaan meningkatkan leverage maka perusahaan ini dengan sendirinya akan menanggung risiko keuangan yang lebih meningkat. (Priyono, 2015).

\section{Pertumbuhan Asset}

Pertumbuhan total aktiva suatu perusahaan juga mencerminkan prospek perusahaan dimasa mendatang, tetapi membawa implikasi yang berbeda terhadap tingkat utang. Pertumbuhan total aktiva cenderung berdampak positif terhadap tingkat utang perusahaan. Pertumbuhan total aktiva perusahaan mencerminkan horizon waktu yang lebih panjang untuk kegiatan investasi perushaan. Peningkatan aktiva dilakukan perusahaan bila terdapat prospek yang baik. Kebutuhan dana internal yang tidak mencukupi akan mendorong perusahaan menggunakan utang, sehingga pertumbuhan total aktiva cenderung berdampak positif terhadap tingkat utang perusahaan.

\section{Pertumbuhan Penjualan}

Pertumbuhan penjualan merupakan cerminan dari besar kecilnya suatu perusahaan. Besar kecilnya suatu perusahaan akan menggambarkan bagaimana karakteristik yang dimiliki oleh perusahaan terkait dengan keputusan manajemen, kinerja keuangan perusahaan, dan aktivitas suatu perusahaan. Total aktiva, penjualan dan kapitalisasi pasar dapat digunakan untuk menentukan ukuran perusahaan karena 
mampu mewakili seberapa besar perusahaan tersebut. Semakin besar aktiva menggambarkan bahwa semakin banyak modal yang ditanam oleh perusahaan tersebut, semakin banyak penjualan maka semakin banyak tingkat pengembalian yang diperoleh dari perputaran aktiva perusahaan, dan semakin besar kapitalisasi pasar maka semakin dikenal oleh publik, baik itu investor maupun stakeholder perusahaan (Sudarmadji dan Sularto, 2015).

\section{Profitabilitas}

Profitabilitas adalah suatu analisis yang digunakan mengendalikan laba yang diperoleh. Suatu perusahaan harus memperoleh laba agar dapat terus tumbuh dan berkembang untuk waktu yang relatif lama. Namun dalam menjalankan perusahaan, manajemen tidak selalu memperoleh laba yang sebesarbesarnya. Seandainya hal ini terjadi, perusahaan tersebut akan cenderung mengeksploitasi sumber daya yang dimiliki atau melakukan tindakan-tindakan yang tidak sesuai dengan etika bisnis yang berlaku. Karena itu, kebijakan mengenai laba harus seimbang dengan kebijakan peningkatan kesejahteraan karyawan dan kebijakan peningkatan kemakmuran masyarakat secara luas.

\section{METODE PENELITIAN}

Penelitian ini dilakukan di PT. Bursa Efek Indonesia (BEI) yang menyediakan informasi laporan keuangan perusahaan dengan mengakses situs resmi Bursa Efek Indonesia website www.idx.co.id penelitian dilaksanakan terhadap laporan keuangan selama empat tahun dari tahun 2015-2018. Dalam penelitian ini seluruh Perusahaan Pertambangan yang Terdaftar di Bursa Efek Indonesia Tahun 2015-2018 yang berjumlah 46 perusahaan. sedangkan ukuran ampel adalah banyaknya objek psikologis yang digunakan sebagai responden. Metode pengambilan sampel yang digunakan dalam penelitian ini adalah metode purposive sampling. Adapun kreteria penentuan sampel adalah:

a. Perusahaan pertambangan yang terdaftar di Bursa Efek Indonesia, dengan kreteria terdaftar sebagai perusahaan publik tahun 2015-2018. 
b. Perusahaan petambangan yang telah mempublikasikan laporan keuangan berturut-turut dari tahun 2015-2018.

c. Perusahaan pertambangan yang mendapatkan nilai price earning rasio berturut-turut dari tahun 2015-2018.

Metode Purposive Sampling

\begin{tabular}{|l|l|c|}
\hline No & Kreteria & $\begin{array}{l}\text { Jumlah } \\
\text { Perusahaan }\end{array}$ \\
\hline 1. & $\begin{array}{l}\text { Perusahaan pertambangan yang terdaftar di Bursa Efek } \\
\text { Indonesia, dengan kreteria terdaftar sebagai purusahaan } \\
\text { publik tahun 2015-2018 }\end{array}$ & 46 \\
\hline 2. & $\begin{array}{l}\text { Perusahaan pertambangan yang tidak mempublikasikan } \\
\text { laporan keuangan berturut-turut dari tahun 2015-2018 }\end{array}$ & $(6)$ \\
\hline 3. & $\begin{array}{l}\text { Perusahaan pertambangan yang tidak mendapatkan nilai } \\
\text { berturut-turut dari tahun 2015-2018. }\end{array}$ & $(20)$ \\
\hline & Total sampel penelitian & 20 \\
\hline
\end{tabular}

Sumber: $\underline{\text { ww.idx.co.id }}$

\section{HASIL DAN PEMBAHASAN}

\section{Pengaruh pertumbuhan asset terhadap struktur modal.}

Berdasarkan hasil analisis data dapat diketahui bahwa perrtumbuhan asset berpengaruh positif dan signifikan terhadap struktur modal pada Perusahaan Pertambangan di Bursa Efek Indonesia periode 2015-2018. Hal ini dapat dilihat dari nilai t-test sebesar 2,109, sisgnifikansi $t$ sebesar 0,038 dan Unstandardized Coefficients (B) sebesar positif 1,223. Dengan demikian hipotesis yang menyatakan "Pertumbuhan asset berpengaruh positif dan signifikan terhadap struktur modal pada Perusahaan Pertambangan di Bursa Efek Indonesia periode 2015-2018" terbukti dan dapat diterima.

\section{Pengaruh Pertumbuhan Penjualan terhadap Struktur Modal.}

Berdasarkan hasil analisis data dalam penelitian ini menunjukkan bahwa pertumbuhan penjualan berpengaruh positif dan signifikan terhadap struktur modal. Hal ini dapat dilihat dari nilai t-test untuk pertumbuhan penjualan sebesar 2,988, sisgnifikansi t sebesar 0,004 dan Unstandardized Coefficients (B) sebesar 
positif 0,075. Dengan demikian hipotesis yang menyatakan "Pertumbuhan penjualan berpengaruh positif dan signifikan terhadap struktur modal pada Perusahaan Pertambangan di Bursa Efek Indonesia periode 2015-2018” terbukti dan dapat diterima.

\section{Pengaruh Pertumbuhan Penjualan terhadap Struktur Modal.}

Berdasarkan hasil dari analisis data diketahui bahwa pertumbuhan penjualan berpengaruh positif dan signifikan terhadap struktur modal. Semakin tinggi pertumbuhan penjualan akan meningkatkan struktur modal perusahaan. Hal ini dapat dilihat dari nilai t-test untuk pertumbuhan penjualan sebesar 2,988, sisgnifikansi t sebesar 0,004 dan Unstandardized Coefficients (B) sebesar positif 0,075. Dengan demikian hipotesis yang menyatakan "Pertumbuhan penjualan berpengaruh positif dan signifikan terhadap struktur modal pada Perusahaan Pertambangan di Bursa Efek Indonesia periode 2015-2018" terbukti dan dapat diterima.

\section{E. PENUTUP}

Adapun simpulan dari uraian berdasarkan diatas maka menyatakan bahwa:

1. Pertumbuhan asset berpengaruh positif dan signifikan terhadap struktur modal pada Perusahaan Pertambangan di Bursa Efek Indonesia periode 20152018.

2. Pertumbuhaqn penjualan berpengaruh positif dan signifikan terhadap struktur modal pada Perusahaan Pertambangan di Bursa Efek Indonesia periode 20152018.

3. Profitabilitas berpengaruh positif dan signifikan terhadap struktur modal pada Perusahaan Pertambangan di Bursa Efek Indonesia periode 2015-2018. 


\section{DAFTAR PUSTAKA}

Afza dan Adnan 2012. "Impact of Aggressive Working Capital Management Policy on Firms' Profitability". The IUP Journal of Applied Finance. Vol 15(8), pp. 20-30.

Fahmi, Irham. 2010. Manajemen Kinerja. . Bandung: Alfabet.

Herlina, Husein. 2011. Pengaruh growth opportunity dan firm size terhadap struktur modal pada perusahaan pertambangan di BEI periode 2004 2007. Journal Manajemen Bisnis. Vol 1, No.2.

Priyono, Anggun Dwi. 2011. Pengaruh Promosi Dan Kualitas Pelayanan Terhadap Kepuasan Pengunjung Melalui Keputusan Pengunjung Sebagai Variabel Intervening Pada Objek Wisata Museum Sangiran Kabupaten Sragen. Skrpsi. Fakultas Ekonomi Universitas Negeri Semarang

Saidi. 2004. Faktor-faktor yang Mempengaruhi Struktur Modal pada Perusahaan Manufaktur Go Public di BEJ Tahun 1997-2002. Jurnal Bisnis dan Ekonomi. Vol.11,No.1,Maret 2004.

Sartono, Agus. 2001. Manajemen Keuangan Teori dan Aplikasi. Yogyakarta: BPEF-YOGYAKARTA.

Sunarwi, 2010. “Analisis Faktor-faktor Yang Mempengaruhi Struktur Modal Serta Dampak Struktur Modal Terhadap Return Saham Perusahaan Manufaktur Yang Terdaftar di BEI Periode 2006-2008” Semarang Skripsi. Fakultas Ekonomi Universitas Diponogoro

Sujoko dan Soebiantoro, U., 2007. Pengaruh Struktur Kepemilikan Saham, Leverage, Faktor Intern dan Faktor Ekstern terhadap Nilai Perusahaan, Jurnal Manajemen dan Kewirausahaan, Vol 9, 47. 